\title{
Mango Tree Response to Lime Applied during the Production Phase
}

\author{
Eliozéas Vicente de Almeida ${ }^{1}$, Francisco Maximino Fernandes ${ }^{1}$, Renato de Mello Prado ${ }^{2 *}$, \\ Aparecida Conceição Boliani ${ }^{1}$, Luiz de Souza Corrêa ${ }^{1}$
}

${ }^{1}$ São Paulo State University, Campus Jaboticabal, Brazil; ${ }^{2}$ São Paulo State University, Campus Ilha Solteira, Brazil. Email: *rmprado@fcav.unesp.br

Received April $2^{\text {nd }}, 2012$; revised May $6^{\text {th }}, 2012$; accepted May $25^{\text {th }}, 2012$

\begin{abstract}
Tropical soils are usually highly acidic and this may hamper mango trees nutrition and production. The objective of this work was to evaluate the effects of lime doses applied to the soil surface on the plant nutritional status, the production, and the technological quality of mango fruits. The study was carried out at Selviria, in the state of Mato Grosso, Brazil, in a Typic Haplustox. Thirteen year old producing mango plants of the "Heden" variety, grafted on rootstock of the "Coquinho" variety, were used in this experiment. Lime doses of $0,1.55,3.10,4.655$, and $6.20 \mathrm{t} \cdot \mathrm{ha}^{-1}$ were applied to the soil. Each treatment was replicated 4 times and the experimental units distributed according to a randomized complete block design. Lime $\left(\mathrm{CaO}: 390 \mathrm{~g} \cdot \mathrm{kg}^{-1} ; \mathrm{MgO}: 130 \mathrm{~g} \cdot \mathrm{kg}^{-1}\right)$ was superficially applied to the soil and then incorporated at depths between 0 and $5 \mathrm{~cm}$ in the total area of the orchard. The soil chemical characteristics $\mathrm{pH}, \mathrm{Ca}, \mathrm{Mg}, \mathrm{K}$, sum of bases, and bases saturation, in the $0-20 \mathrm{~cm}$ layer, were evaluated 16 and 28 months after soil liming. Plant nutritional status was evaluated 12 months after soil liming. Fruit production and technological quality were evaluated during the cropping years of 2006 and 2007. Soil liming had a positive effect on the evaluated soil chemical characteristics and this improved plant nutritional status and fruit technological quality as well as increased fruit production. These beneficial effects though were observed only in the second year after soil liming. The highest fruit production was verified when soil bases saturation was of $72 \%$ and the contents of $\mathrm{Ca}$ and $\mathrm{Mg}$ were of 32 and $8 \mathrm{~g} \cdot \mathrm{kg}^{-1}$, respectively.
\end{abstract}

Keywords: Mangifera indica L.; Productivity; Soil Acidity; Savannah

\section{Introduction}

Mango (Mangifera indica L.) is one of the most important tropical fruits produced in Brazil where it grows in an estimated area, in 2009, of 74,000 hectares, with a fruit production close to 1.1 million tones [1]. The Southeast and Northeast Brazilian regions respond, respectively, for $29 \%$ and $69 \%$ of the total production. Increasing mango production in the central region (where most of the Brazilian savannah is found) of the country demands a better knowledge of its soils restrictions.

The Latosols are the most widely used type of soil for agricultural production in the savannah region, since they represent approximately $46 \%$ of the total area [2]. These are soils characteristically deep and permeable what makes them ideal for fruit production. On the other hand, they are also high in acidity, having high concentrations of $\mathrm{Al}$ and $\mathrm{Mn}$ and low concentrations of bases such as $\mathrm{Ca}$ and $\mathrm{Mg}$. These are characteristics which make them soils of low fertility [3]. In acidic soils mango plants may ex-

"Corresponding author. hibit calcium deficiency what is shown in the plants being short and more chlorotic than the normal ones, the leaves show more darkened margins except at their base and apex, become yellow and fall [4]. Low levels of calcium in the plant may cause the fruit to undergo internal breakdown, making them worthless for consumption [5].

Although mango tree is considered a robust species [6], incrementing fruit production and quality demand soils with corrected acidity.

The response of mango trees growing under conditions of commercial production to the application of lime to the soil was not found in the literature. Although lacking support from research works, indications can be found pointing the ideal $\mathrm{pH}$ for mango trees as being between 5.5 and 6.5 [7] and bases saturation $\left[\mathrm{Ca}^{2+}+\mathrm{Mg}^{2+}+\right.$ $\left.\mathrm{K}^{+} / \mathrm{Ca}^{2+}+\mathrm{Mg}^{2+}+\mathrm{K}^{+}+\left(\mathrm{H}+\mathrm{Al}^{3+}\right)\right]$ of $80 \%[8]$.

Taking in consideration these comments, the objective of this work was to evaluate the effects of doses of lime applied to the soil of a mango orchard on soil fertility, plant nutritional status, and yield and the technological quality of fruits. 


\section{Material and Methods}

The experiment was conducted from May of 2005 through February of 2008 in a mango orchard formed with plants of the "Haden" cultivar, grafted on rootstock of the "Coquinho" variety. The soil was a dystrophic Red Latosol (Typic Haplustox), of clayish texture, located in the experimental farm of the Selviria campus of the São Paulo State University (UNESP), at $20^{\circ} 14^{\prime} \mathrm{S}$ of latitude, $51^{\circ} 10^{\prime} \mathrm{W}$ of longitude and at an altitude of $335 \mathrm{~m}$. The climate is described as of the Aw type according to the Köppen's classification system, with a mean annual temperature of $23.7^{\circ} \mathrm{C}$. The total annual precipitation values were of $1064 \mathrm{~mm}$ in 2005, 1665 in 2006, 1309 in 2007, and $596 \mathrm{~mm}$ in January of 2008.

In March of 2005, soil samples, taken from the plant rows and between rows, were submitted to chemical analyses to determine soil fertility with the following results: $\mathrm{pH}\left(\mathrm{CaCl}_{2}\right): 4.7$ and 4.7, Organic Matter: 30 and 26 $\mathrm{g} \cdot \mathrm{dm}^{-3}, \mathrm{P}$ (resin): 7 and $9 \mathrm{mg} \cdot \mathrm{dm}^{-3}, \mathrm{~K}: 1.5$ and $0.9, \mathrm{Ca}$ : 23 and 16, Mg: 16 and 11, $\mathrm{H}+\mathrm{Al}: 42$ and 42, Al: 3 and 4 $\mathrm{mmol}_{\mathrm{c}} \cdot \mathrm{dm}^{-3}$, and $\mathrm{V}: 49$ and $40 \%, \mathrm{Cu}: 3.6$ and $3.1 \mathrm{Fe}: 42$ and 34, Mn: 13.3 and 9.5, $\mathrm{Zn}: 0.6$ and 0.5 , and B: 0.13 and $0.18 \mathrm{mg} \cdot \mathrm{dm}^{-3}$, respectively.

The treatments were distributed in the field according to a randomized complete block design, with 5 replicates. The amount of lime to be applied was calculated to cause saturation bases to reach $80 \%$. The value taken in consideration was that resulting from the soil sampling made between rows at a depth of $0-20 \mathrm{~cm}$, according to procedures described by Quaggio et al. [8]. Lime $(\mathrm{CaO}=$ $390 \mathrm{~g} \cdot \mathrm{kg}^{-1} ; \mathrm{MgO}=130 \mathrm{~g} \cdot \mathrm{kg}^{-1}$; reactivity of $89 \%$ and Total Neutralization Real Power $=91 \%$ ) was applied on October 25, 2005, all over the area. After being spread all over the orchard surface, the lime was incorporated at a depth between 0 and $5 \mathrm{~cm}$ with the help of a light disk harrow implement.

The treatments consisted of lime doses which were values having as a referential the calculated lime dose to raise $\mathrm{V}$ to $80 \%$ at the depth of $0-20 \mathrm{~cm}$. The referential dose was of $3.1 \mathrm{t} \cdot \mathrm{ha}^{-1}$ and the treatments were as follows: $\mathrm{T}_{1}$ : no lime, $\mathrm{T}_{2}$ : half the referential dose, $\mathrm{T}_{3}$ : the referential dose, $\mathrm{T}_{4}: 1.5$ times the referential dose, $\mathrm{T}_{5}: 2$ times the referential dose, or, in other words, the doses were of $0,1.55,3.10,4.65$, and $6.20 \mathrm{t}$ of lime per hectare. The experimental unit was formed by five $10 \times 10 \mathrm{~m}$ spaced plants. The three central plants of the experimental unit were those used for measuring the effects of the applied treatments.

The experiment started on april of 2005. Initially, the plants were pruned viewing the elimination of apical dominance, according to recommendation by Kavati [9]. Pruning for cleaning effects was performed after harvest, during the months of March of 2006 and 2007. Cultural practices viewing the control of weeds, insects and dis- eases were made.

During the cropping years of 2005/06 and 2006/07, fertilization viewing to preserve $\mathrm{N}, \mathrm{P}$, and $\mathrm{K}$ levels in the soil was made with basis on soil analysis, according to procedures described by Quaggio et al. [8]. The following amounts of fertilizers (in $\mathrm{kg} \cdot \mathrm{ha}^{-1}$ ) were applied: 30 of $\mathrm{N}$ (in urea), 40 of $\mathrm{P}_{2} \mathrm{O}_{5}$ (in simple superphosphate), 39 of $\mathrm{K}_{2} \mathrm{O}$ (in potassium chloride), 2 of $\mathrm{B}$ (in boric acid), and 1 of $\mathrm{Zn}$ (in zinc sulfate). Phosphorus and the micronutrients were all applied in December of 2005 and repeated in december of 2006. N and $\mathrm{K}$ had their doses divided by 3 : the first part applied during december, the second during march/april and the third in may. All nutrients were manually spread on the soil surface in an area corresponding to the plant aerial part projection.

Soil samples were taken 16 and 28 months after the liming procedures at a mean distance of $2 \mathrm{~m}$ from the tree trunk at a depth of $0-20 \mathrm{~cm}$. In these samples, the following chemical characteristics were measured: $\mathrm{pH}, \mathrm{K}$, $\mathrm{Ca}, \mathrm{Mg}, \mathrm{H}+\mathrm{Al}$, according to methodology recommended by Raij et al. [10]. The soil sum of bases $\left(\mathrm{Ca}^{2+}+\right.$ $\left.\mathrm{Mg}^{2+}+\mathrm{K}^{+}\right)$and bases saturation were calculated.

At flowering, 12 months after soil liming, plants nutrional status was evaluated in two central leaves from the second terminal branch flux at the median part of the plant on the four cardinal points, according to procedures recommended by Silva et al. [11]. These leaves served for determining $\mathrm{Ca}$ and $\mathrm{Mg}$ levels according to procedures found in Bataglia et al. [12]. Number and weight of fruits in two harvests (November and December) were also determined. The fruits had their $\mathrm{pH}$ and soluble solids content (Brix) determined by a refractometer and their titratable acidity (g of citric acid per $100 \mathrm{~g}$ of pulp) by method proposed by Tressler \& Loslyn [13].

The data resulting from the experiment were submitted to the analysis of variance according to procedures found in Ferreira [14]. The statistical model used was that of split plots for the analysis of variance for soil and sampling time. Following that, the effects of lime doses on the studied variables were compared by means of polynomial regression studies.

\section{Results and Discussion}

The results show that no significant interaction was found between lime doses and sampling time (data not shown). Soil liming improved soil reaction chemistry, increasing $\mathrm{pH}$ (Figure 1(a)), decreasing $\mathrm{H}+\mathrm{Al}$ (Figure 1(b)), increasing the bases $\mathrm{Ca}$ and $\mathrm{Mg}$ (Figure 1(c)) which resulted in an increased sum of bases (Figure 1(d)), and in bases saturation (Figure 1(e)). These results are similar to those presented by several authors in which lime was spread over the orchard surface such as Correa [15], with guava, and Silva [16], with citrus. 

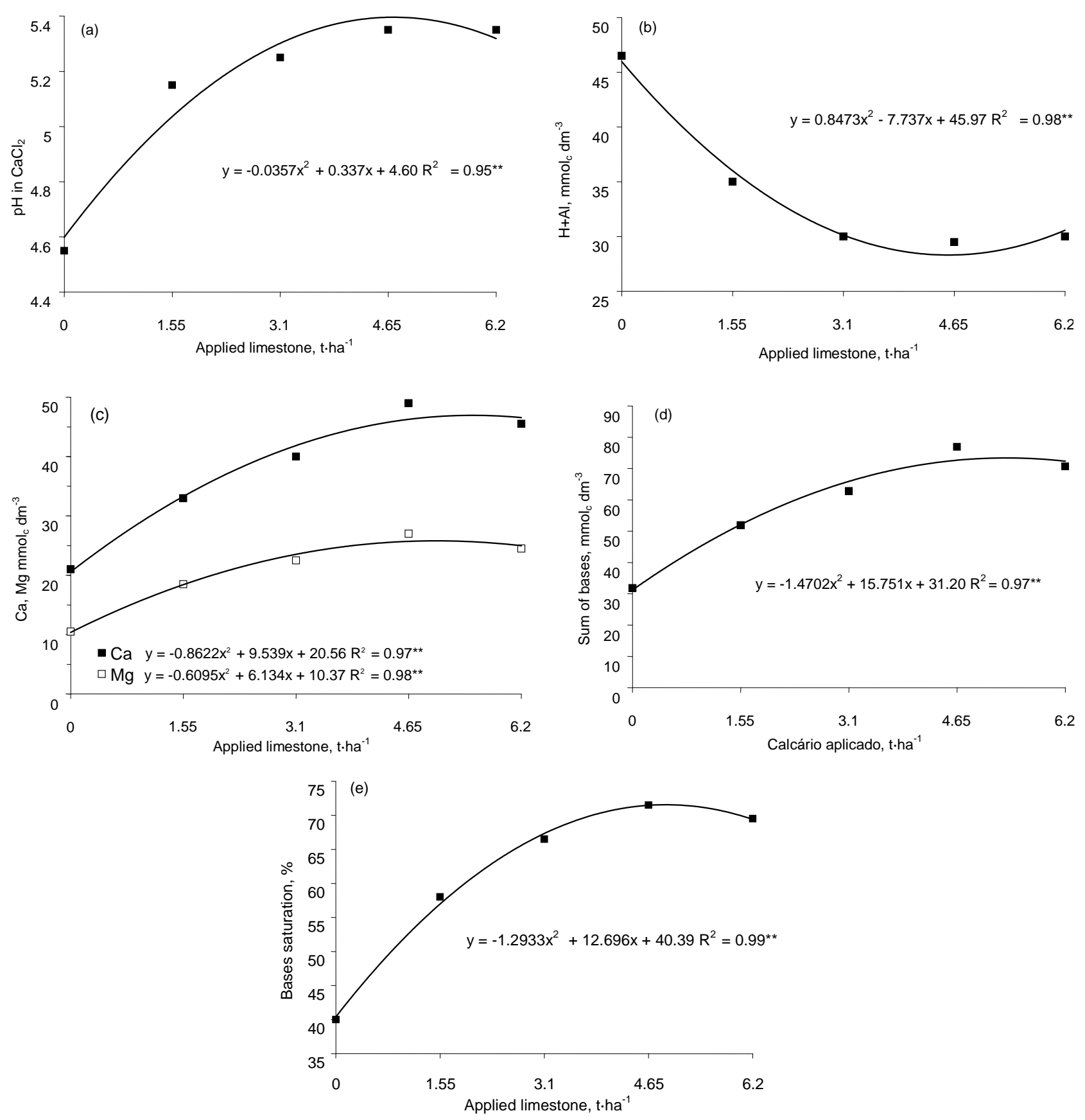

Figure 1. Effects of lime on $\mathrm{pH}\left(\mathrm{CaCl}_{2}\right)(\mathrm{a}), \mathrm{H}+\mathrm{Al}(\mathrm{b}), \mathrm{Ca}, \mathrm{Mg}(\mathrm{c})$, sum of bases (d), and bases saturation (e) at depths between 0 and $20 \mathrm{~cm}$ of a soil being cultivated with mango plants (mean values of two sampling times). **significant by the $\mathrm{F}$ test $(\mathbf{p}<\mathbf{0 . 0 1})$.

It is possible to observe that the dose of $4.65 \mathrm{t} \cdot \mathrm{ha}^{-1}$ (that is a dose 1.5 times larger than the referential dose) resulted in the highest $\mathrm{pH}$ level (5.4) and bases saturation $(72 \%)$. Thus, none of the lime doses used in this experiment was capable of raising bases saturation value to $80 \%$, which was pointed by Quaggio et al. [8] as the ideal one for mango trees. Oliveira et al. [17] also reported that the liming procedure they made use of in their experiment was not capable of raising bases saturation to $80 \%$. Caires and Rosolem [18] have suggested that this type of result may be ascribed to losses of $\mathrm{Ca}$ and $\mathrm{Mg}$ caused by the soil buffering capacity, to the chemical equilibrium between lime reactions, and to the coarseness of lime granulometry - the coarser it is, the more difficult its solubilization in the soil. It is also possible that the time elapsed between lime application and soil 
sampling (22 months) was not sufficient for the complete lime reaction to occur-according to Oliveira et al. [17], the lime reaction with the soil may take 33 months to complete.

The increment in soil bases (Figure 1(e)) by the liming procedure brought about an increment with quadratic adjustment in the leaf contents of $\mathrm{Ca}$ and $\mathrm{Mg}$ (Figure 2). The levels of these nutrients in the leaves in all treatments are to be considered adequate in comparison with those pointed by Quaggio et al. [8] as adequate, that is Ca: $20-35$ and $\mathrm{Mg}: 2.5-5.0 \mathrm{mg} \cdot \mathrm{kg}^{-1}$.

The liming procedure did not affect fruit number $(\mathrm{F}$ : $0.37 \mathrm{~ns}$ ) or production (F: $0.54 \mathrm{~ns}$ ) in the first year of study. In the second year though, soil liming promoted an increment in fruit number with a quadratic adjustment (Figure 3(a)) and also influenced fruit production (Figure 3(b)). Similar results were reported by Fidalski et al. [19] who worked with orange of the "Pera" cultivar. Positive lime effects on fruit production were also reported by Pavan [20], in apple, Prado [21], in starfruit, Natale et al. [22], in guava, and Prado et al. [23], in passion fruit.

These effects of liming on mango production are to be ascribed to the improvement of soil chemical attributes
(Figure 1) and of the plant nutritional status (Figure 2) specially because liming provides the mango plant with $\mathrm{Ca}$ and this is one of the most demanded nutrients by the mango plant [11]. Ca is responsible for a larger development of the root system of fruiting plants [24] and these more voluminous root systems cause the plant to absorb higher quantities of other mineral nutrients and this permits larger productions of fruits.

The results show that the highest fruit yield was verified when the lime dose was of $4.6 \mathrm{t} \cdot \mathrm{ha}^{-1}$ (Figure 3(b)) and that at that point soil saturation bases was of $72 \%$ (Figure 1(e)). This value is a little below that indicated by Quaggio et al. [8] as being the adequate one, that is, $80 \%$, although these authors do not inform whether this value is applicable for the moment the crop is implanted or for when it reaches the production phase. The lime dose that permitted the highest productivity was associated with $\mathrm{Ca}$ and $\mathrm{Mg}$ foliar levels of 31.9 and $8.2 \mathrm{~g} \cdot \mathrm{kg}^{-1}$, respectively. These values are in accordance with those indicated by Quaggio et al. [8], that is, Ca from 20 to 35 $\mathrm{g} \cdot \mathrm{kg}^{-1}, \mathrm{Mg}$ from 2.5 to $5.0 \mathrm{~g} \cdot \mathrm{kg}^{-1}$ and Malavolta et al. [25], that is, Ca from 30 to $33 \mathrm{~g} \cdot \mathrm{kg}^{-1}$ and $\mathrm{Mg}$ from 5 to 6 $\mathrm{g} \cdot \mathrm{kg}^{-1}$.

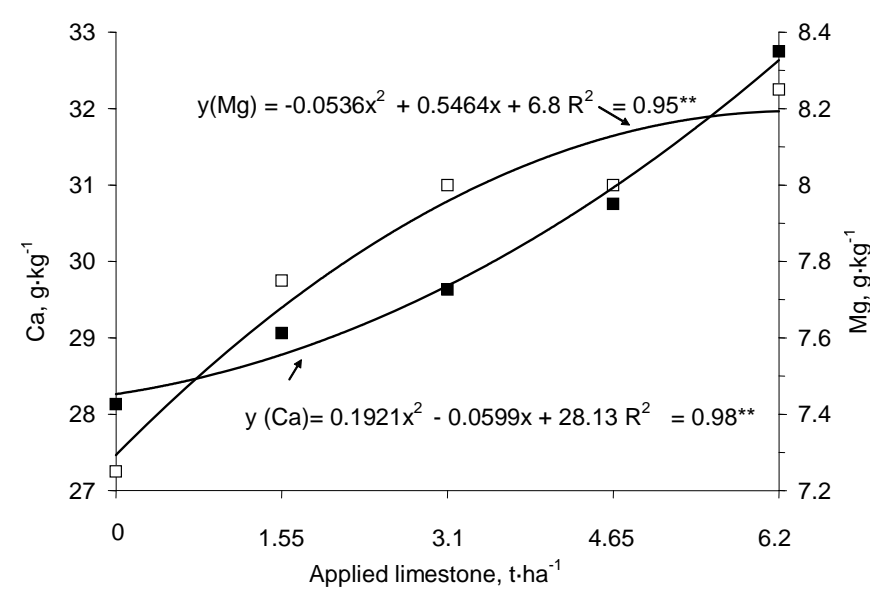

Figure 2. Soil liming effects on Ca and Mg leaf contents of mango plants of the "Haden" cultivar.
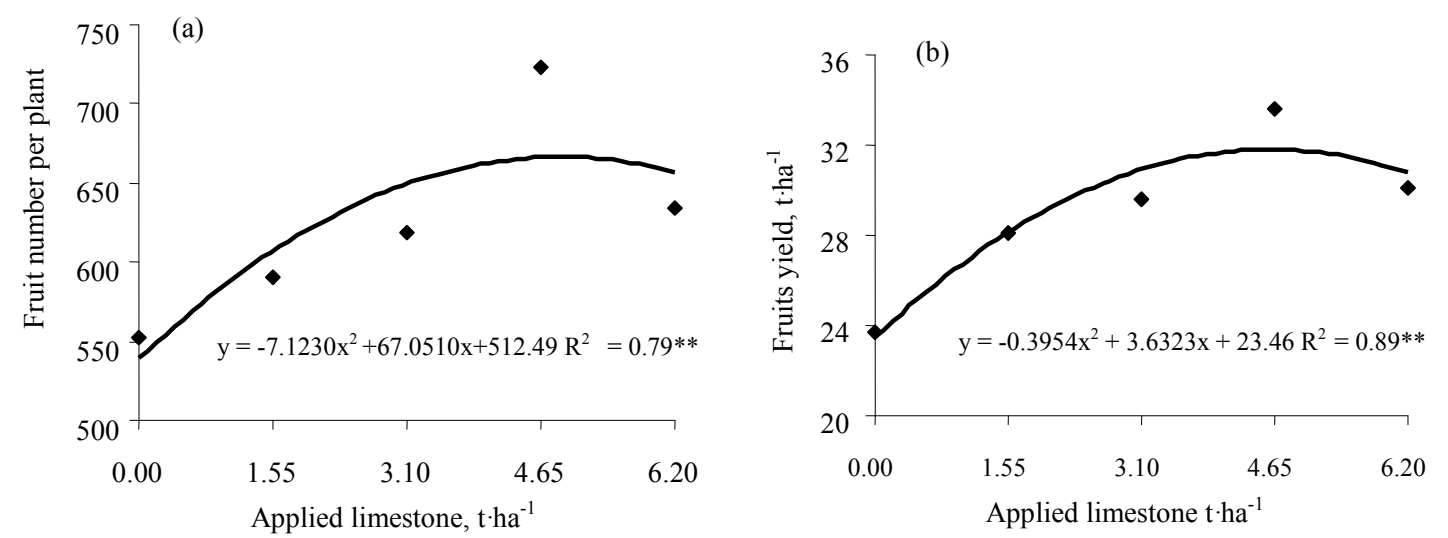

Figure 3. Soil liming effects on fruit number (a) and productivity (b) of mango plants of the "Haden" cultivar. 
Lime doses caused linearly adjusted increments in fruit $\mathrm{pH}$ values during the two years of the experiment (Figure 4(a)) and, in the titratable acidity, quadratically adjusted reductions during the harvest of 2006 and linearly adjusted reductions during the harvest of 2007 (Figure 4(b)). During the second year of harvest the titratable acidity of fruits was lower and higher $\mathrm{pH}$ when in comparison with the first year and this is understood as an indication of the liming effect. According to Manica [26], the mango fruits adequate titratable acidity values should be between 0.11 and $0.56 \%$. It can thus be seen that the results found in this work are in agreement with those pointed by that author with the exception of those of the check treatment and of the lime dose of $1.55 \mathrm{t} \cdot \mathrm{ha}^{-1}$ (Figure 4(b)). This reduction in the titratable acidity of fruits when lime is applied to the soil was also reported by Leal et al. [27] in starfruit.

The results also show that the amount of soluble solids was not affected $(\mathrm{F}=0.53 \mathrm{~ns})$ during the first year by the liming procedures. In the second year though the amount of soluble solids increased with a linear adjustment with lime doses (Figure 4(c)). Rotondano \& Melo [28], Leal et al. [27], Paro et al. [29] report to have observed that soil liming resulted in fruits with higher levels of soluble solids and this resulted in the fruits reaching the harvest point more precociously. The levels of soluble solids found in this research work (Figure 4(c) 15.8 and 17.6) are in accordance with those indicated as adequate for mango fruits by Manica et al. [26], that is, between $11.9 \%$ and $28.2 \%$.

\section{Conclusions}

Soil liming improved soil chemical attributes and this resulted in improved plant nutritional status and in higher fruits yield as well as fruits of better technological quality.

Soil liming effects on adult mango plants is slow and it causes significant effects on fruit yield only in the second year following liming.

The highest mango fruit production took place when soil liming caused bases saturation to reach a value of $72 \%$ and $\mathrm{Ca}$ an $\mathrm{Mg}$ foliar levels of 32 and $8 \mathrm{~g} \cdot \mathrm{kg}^{-1}$, respectively.

\section{Acknowledgements}

The authors are thankful to Empresa Baiana de Desenvolvimento Agricola S.A. and to the São Paulo State
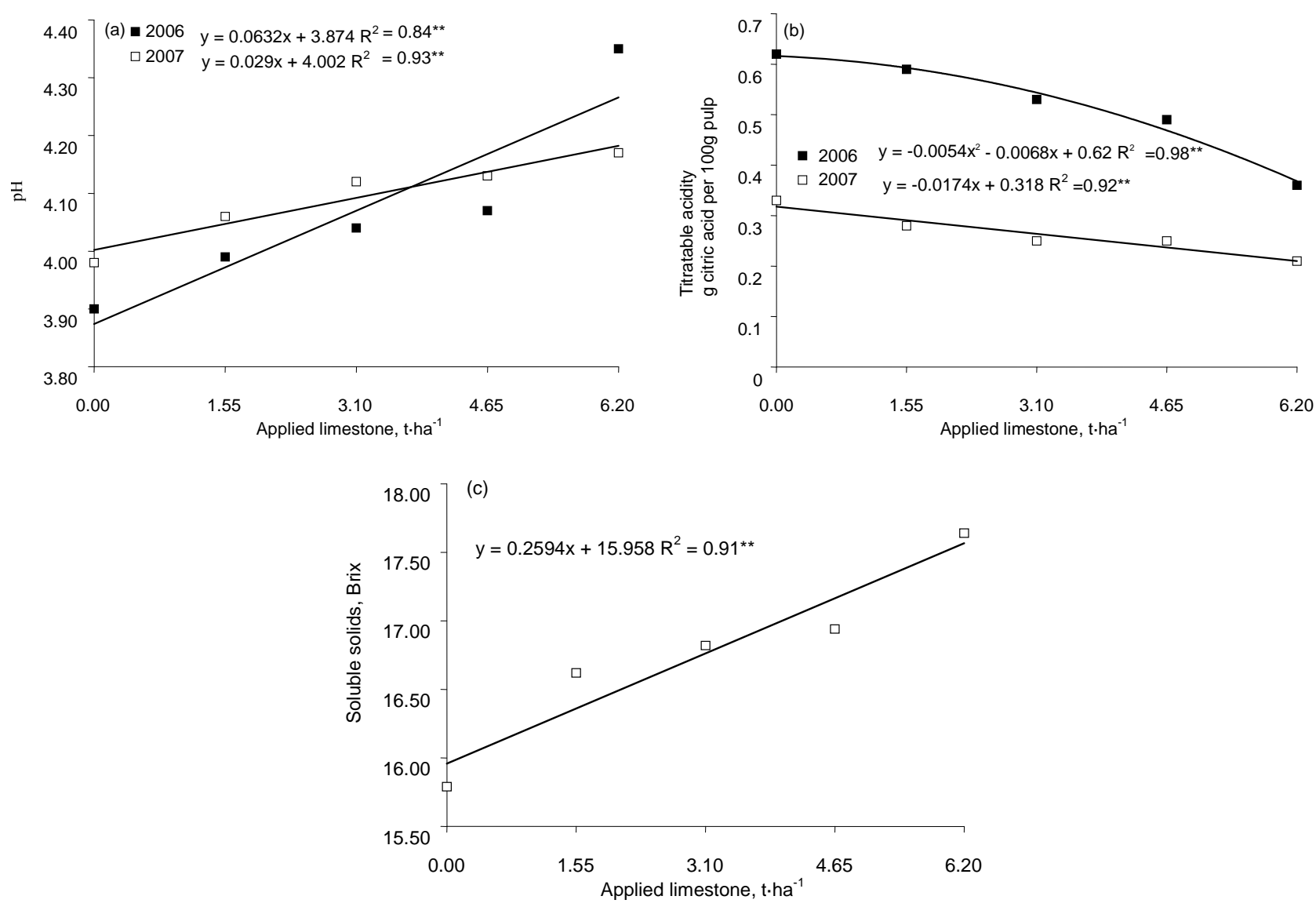

Figure 4. Soil liming effects on pH (a), titratable acidity (b), and solid solubles (c) of mango fruits of the "Haden” cultivar. 
University (UNESP), campus of Ilha Solteira.

\section{REFERENCES}

[1] Agrianual, "Anuário da Agricultura Brasileira," FNP Consultoria \& Comércio, São Paulo, 2011, pp. 380-386

[2] J. Adámoli, J. Macêdo, L. G. Azevedo and J. Madeira Netto, "Caracterização da Região dos Cerrados," In: W. J. Goedert, Ed., Solos dos Cerrados, EMBRAPA/Nobel, São Paulo, 1987, pp. 33-74.

[3] P. A. Sanchez and J. G. Salinas, "Suelos Acidos: Estrategias para su Manejo con Bajos Insumos en America Tropical," Bogotá, La Sociedad Colombiana de la Ciencia del Suelo, 1983, p. 93

[4] S. Kumar and J. P. Nauriyal, "Nutritional Studies on Mango: Tentative Leaf Analysis Standards," Indian Journal of Horticulture, Vol. 34, 1977, pp. 100-106.

[5] A. Cracknell Torres, M. C. Cid, A. R. Socorro, D. Fernández, P. Rosell and V. Galán, "Effects of Nitrogen and Calcium Supply on the Incidence of Internal Fruit Breakdown in 'Tommy Atkins' Mangoes (Mangifera indica L.) Grown in a Soilless System," Acta Horticulturae, Vol. 645, 2004, 387-393.

[6] P. T. G. Guimarães, "Nutrição e Adubação da Mangueira," Informe Agropecuário, Vol. 8, No. 86, 1982, pp. 28-35.

[7] L. A. A. Rovira and C. R. Alvarez, "El Mango (Mangifera indica L.)," Editoral America, Caracas, 1990, $401 \mathrm{p}$.

[8] J. A. Quaggio, B. Van Raij and C. T. Piza Junior, "Frutíferas," In: B. Van Raij, H. Cantarella, J. A. Quaggio and A. M. C. Furlani, Eds., Recomendações de adubação e Calagem para o Estado de São Paulo, Instituto Agronômico/Fundação IAC, Campinas, 1997, pp. 121-153.

[9] R. Kavati, "Práticas Culturais em Mangueiras no Estado de São Paulo," In: Simpósio Sobre Mangicultura, FINEP, Jaboticabal, 1989, pp. 99-108.

[10] B. Van Raij, J. C. Andrade, H. Cantarella, J. A. and Quaggio (Eds.), "Análise Química para Avaliação da Fertilidade de solos Tropicais," Instituto Agronômico, Campinas, 2001, $285 \mathrm{p}$.

[11] D. J. Silva, J. A. Quaggio, P. A. C. Pinto, A. C. Q. Pinto and A. F. J. Magalhães, "Nutrição e Adubação," In: P. J. C. Genú and A. C. Q. Pinto, Eds., A Cultura da Mangueira, Brasília, Embrapa Informação Tecnológica, 2002, pp. 192-221.

[12] O. C. Bataglia, A. M. C. Furlani, J. P. F. Teixeira, P. R. Furlani and J. R. Gallo, "Métodos de Análise Química de Plantas," Instituto Agronômico de Campinas, Campinas, 1983, 48 p.

[13] D. K. Tressler and M. A. Loslyn, "Fruits and Vegetables Juice Processing Technology," The AVI Publications, Westport, 1961, $1028 \mathrm{p}$.

[14] D. F. Ferreira, "Análises Estatísticas por Meio do Sisvar para Windows Versão 4.1," In: Reunião Anual da Região Brasileira da Sociedade Internacional de Biometria, UFSCar, São Carlos, 2000, pp. 255-258.
[15] M. C. M. Corrêa, "Calagem em Pomar de Goiabeiras em Produção e em Colunas de Solo," Tese (Doutorado em Produção Vegetal)—Faculdade de Ciências Agrárias e Veterinárias, Universidade Estadual Paulista, Jaboticabal, 2004.

[16] M. A. C. Silva, W. Natale, R. M. Prado, M. C. M. Corrêa and E. S. Sthuchi, "Aplicação de Calcário em Pomar de Laranjeira pêra em Produção," Revista Brasileira de Fruticultura, Vol. 29, 2007, pp. 606-612. doi:10.1590/S0100-29452007000300036

[17] E. L. Oliveira, M. S. Parra and A. Costa, "Resposta da Cultura do Milho, em um Latossolo Vermelho-Escuro álico, à Calagem," Revista Brasileira de Ciência do Solo, Vol. 21, n.1, 1997, pp. 65-70.

[18] E. F. Caires and C. A. Rosolem, "Calagem em Genótipos de Amendoim," Revista Brasileira de Ciência do Solo, Campinas, Vol. 17, No. 2, 1993, pp. 193-202.

[19] J. Fidalski, M. A. Pavan, P. A. M. Auler and A. P. Jacomino, "Produção de Frutos de Laranjeira Pêra e teores de Nutrientes nas Folhas e no solo, em Latossolo Vermelho-Escuro do Noroeste do Paraná," Revista Brasileira de Ciência do Solo, Vol. 23, No. 2, 1999, pp. 273-279.

[20] M. A. Pavan, "Manejo da Calagem em Pomares Estabelecidos de Macieira," Pesquisa Agropecuária Brasileira, Vol. 27, No. 2, 1992, pp. 271-276.

[21] R. M. Prado, W. Natale and D. E. Rozane, "Soil Liming Effects on the Development and the Nutritional Status of the Carambola Tree and Its Fruit Yielding Capacity," Communications in Soil Science and Plant Analysis, Vol. 38, 2007, pp. 493-511. doi: $10.1080 / 00103620601174536$

[22] W. Natale, R. M. Prado, D. R. Rozane and L. M. Romualdo, "Efeitos da Calagem na Fertilidade do solo e na Nutrição e Produtividade da Goiabeira," Revista Brasileira de Ciência do solo, Viçosa, Vol. 31, No. 6, 2007, pp. 1475-1485.

[23] R. M. Prado, W. Natale, M. C. M. Correa and L. F. Braghirolli, "Efeitos da Aplicação de Calcário no Desenvolvimento, no Estado Nutricional e na Produção de Matéria seca de Mudas de Maracujazeiro," Revista Brasileira de Fruticultura, Vol. 26, 2004, pp. 145-149. doi:10.1590/S0100-29452004000100039

[24] R. M. Prado and W. Natale, "Calagem na Nutrição de Cálcio e no Desenvolvimento do Sistema Radical da Goiabeira," Pesquisa Agropecuária Brasileira, Vol. 39, No. 10, 2004, pp. 1007-1012. doi:10.1590/S0100-204X2004001000008

[25] E. Malavolta, G. C. Vitti and S. A. Oliveira, "Avaliação do estado Nutricional das Plantas: Princípios e Aplicações," 2nd Edition, POTAFÓS, Piracicaba, 1997, 319 p.

[26] I. Manica, "Colheita-Embalagem-Armazenamento," In: I. Manica, Ed., Manga: Tecnologia, Produção, Agroindústria e Exportação, Cinco Continentes, Porto Alegre, 2001, pp. 436-444.

[27] R. M. Leal, R. M. Prado and W. Natale, "Calagem nas Características Físicas e Tecnológicas de Frutos da Caramboleira, (s.1.: s.n., 2005)," 2008. 
http://www.todafruta.com.br

[28] A. K. F. Rotondano and B. Melo, "Núcleo de Estudo em Fertilidade no Cerrado. (s.l.: s.n.)," 2003.

http: /www.fruticultura.iciag.ufu.br/aduba5.html

[29] M. Paro, G. C. Vitti, L. C. Donadio and O. R. Sempionato,
"Influência da Utilização de Dois Corretivos Agrícolas, Calcário e o Gesso na Qualidade do Fruto da Laranjeira pêra," In: Congresso Brasileiro de Fruticultura, Sociedade Brasileira de Fruticultura, Salvador, 1994, p. 511. 